\title{
ISLAMIC FINANCE \\ A BULWARK AGAINST CONTAGION IN THE GLOBAL BANKING SYSTEM
}

\author{
Amer Al-Roubaie"
}

\begin{abstract}
The objective of this article is to shed some light on the performance of Islamic financial institutions in view of the current global financial crisis. Islamic financial activities and products are conducted in compliance with the sharīah and, therefore, they are less vulnerable to changes in monetary variables than conventional financial products. Due to the prohibition of interest and because of ethical and moral constraints, Islamic banks are restricted from investment in speculative transactions which lessens default risk and enhances effectiveness of liquidity management. Islamic modes of investment contribute to society's wellbeing through the creation of wealth and employment to ensure economic stability and human development. In Islam, knowledge, information and work are the main ingredients for success (falāh). In an information-intensive world, honesty, accountability and transparency are vital for market performance and business activities. The global financial crisis has caused instability in financial markets weakening confidence in the global economic system as well as increasing uncertainty about future macroeconomic trends.
\end{abstract}

\section{Introduction}

Seldom do crises create shock waves that impact the economies of so many countries as the one currently sweeping across financial institutions worldwide. The present crisis is a product of human misconduct and inadequate regulatory standards by central banking and monetary authorities. So far, the magnitude of the crisis is estimated to have erased about US\$50 trillion in financial assets worldwide. In the Muslim world, although it is difficult to estimate the losses, the Gulf Arabs alone are said to have lost US $\$ 2$ trillion. For example, in Dubai almost 40 per cent of the work in the construction sector has been put on hold throwing thousands of people out of work. The fear prevails that the impact of the global financial crisis will have severe consequences far beyond the economic and financial sectors to

* Prof. Dr Amer Al-Roubaie is Professor of Economics and currently the Dean of the College of Business and Finance at Ahlia University in the Kingdom of Bahrain. 
include the social, political and environmental spheres. In particular, the developing countries will suffer a great deal due to the fall in commodity prices on which their export economies are based. The terms of trade of many nations are expected to deteriorate causing a combination of balance of payments disequilibrium, exchange rate devaluation, budget deficits, higher prices and unemployment.

The crisis has developed on the capability of international financial institutions to provide loans, particularly to poor countries. The consequences of the crisis could have a destabilising effect by increasing social intolerance and political instability. Minimising the risk of economic imbalances, Muslim countries must increase cooperation and strengthen the confidence in financial markets. The capitalist economic system, currently practised in a number of Muslim countries, seems to have suffered a deadly blow, and, therefore, the time has come to reengineer the economic structure and restore confidence in the financial institutions. As an alternative, the Islamic financial system could provide greater financial stability by introducing ethical guidelines to ensure social justice and promote economic growth. Interest payments on bank loans could increase speculation about future economic trends causing negative impact on investment decisions and business transactions.

Currently, the global financial system rests on riba (usury) transactions driven by profit motivation with little attention paid to economic incentives and social safety nets. Capitalism advocates individual freedom and judgment in decision making which causes corruption, mismanagement, fraud and market imperfections. The financial crisis is a product of mismanagement, lack of regulatory measures, poor supervision, inefficiency and speculation. As a result, millions of people have lost their savings with little prospect for recovery.

The causes of the current crisis involve the biggest economy in the world, the United States market. The collapse of the US real estate market followed by mortgage-backed securities markets were among the important factors that were responsible for the current crisis in the global financial markets.

The aim of this article is to shed some light on the Islamic financial system under the current conditions of global financial crisis. During the last few decades, Islamic banking and finance has become popular among investors both in the Muslim world and globally. Being in compliance with the sharì $a h$, or the Islamic legal system, Islamic financial products exhibit ethical and moral guidelines. This chapter examines the causes and consequences of the global financial crisis from an Islamic perspective with a view demonstrating that Islamic financial institutions could provide an alternative to conventional finance. Literature on Islamic banking and finance in recent years has focused on both micro and macro dimensions of the Islamic financial system. These discourses have increased our understanding of the opportunities and challenges in the wake of the global financial crisis facing 
Islamic financial institutions which hold out the future prospect of an alternative to the capitalist financial system.

\section{The Global Financial System and the Crisis of Capitalism}

The magnitude of the global financial crisis has shed doubt on the capability of the capitalistic financial system to keep pace with the recent changes driven by globalisation. Liberalisation of finance and trade, the emergence of information and telecommunication technologies, and rapid capital mobility has increased the flows of trade, capital and finance across countries. This, in turn, increased the risk of global linkages by subjecting financial institutions, both locally and internationally to a high degree of instability. The global financial system is highly interconnected through international trade transactions and multinational business. However, both Western countries and multinational corporations exercise a substantial influence over trade movement, capital flows and financial markets. In practice, the global financial system currently exhibits a free market philosophy based on market freedom and individual decisions with regard to financial transactions and monetary trends. Since its inception in 1944, the International Monetary Fund (IMF) has been a key player in formulating policies and making decisions governing the global financial markets. The structural adjustment programme of the IMF has adopted free market values as guidelines for lending policies, especially in developing countries. Granting of loans is tied to market freedom and low levels of government interference in economic and financial activities. Such policies have forced many countries to withdraw incentives and support local producers from multinational corporations.

Financial institutions, directly affected by the current crisis have pulled the global economy into recession. Many countries, especially non-industrialised countries, are suffering from balance of payments disequilibrium and shortages of liquidity to meet their import requirements. International trade transactions are directly linked to financial flows and foreign direct investment (FDI), and, therefore, a high degree of financial instability causes an adverse effect on economic growth. A recent report by the World Trade Organization (WTO) estimates that the global gross domestic product (GDP) is expected to shrink by 9 per cent in 2009. Slow growth in the global economy reduces aggregate demand resulting in a ripple effect across countries. Without adequate liquidity, the financial system will struggle to meet global financial transactions to service trade and finance. Without a bail out by Western governments a large number of financial institutions would have gone bankrupt. The freedom of the enterprise and individual investors serves only capital owners and profiteers and not necessarily investors. Competition to gain control of the market led to mismanagement, abuse and violation of business ethics. This, however, represents 
an opportunity for Islamic banks to take advantage of the current financial crisis, both locally and globally, to increase the ambit of their financial services worldwide.

The capitalist nature of global financial institutions characterised by oligopolistic market structure generates monetary transactions in the interest of maximising profits. These institutions operate in the short-term pecuniary interest of senior management with little attention paid to the long-term interest of stockholders, let alone the general public. Owing to absence of imperfection of regulation and supervision by government agencies, financial institutions were able to manipulate financial markets in order to gain profit at the expense of long-term interests of the rest of the society. Western governments undertaking to bail out these institutions have burdened themselves with large budget deficits causing constraints on expenditures to alleviate poverty, reduce unemployment, and promote economic growth. The capitalist economic system seems to have reached its limit and, therefore, the role of an unaffected free-market economy will no longer be able to provide practical solutions to modern problems. Policies advocated by international institutions, including the IMF driven by the 'Washington Consensus', have failed to sustain stability in international financial markets.

Finance and financial institutions are at the heart of modern economies reflecting the sensitivity of macroeconomic variables to changes in financial institutions. Furthermore, the crisis will have severe repercussion effects including job losses, social intolerance, economic dislocation and political instability. Similarly, the emergence of such trends will give rise to international tensions by weakening the global financial institutions causing trade, liquidity, capital flows and economic growth to decline.

The extent of the financial crisis and its global implications underscores the importance of international institutional reforms to restore confidence in the global economy. Good governance encompassing structural reform is a must for financial market stability. In the new structure, all countries must be represented including Muslim states. Despite their financial endowment, characterised by their accumulation of petrodollars, Muslim countries have been marginalised by not taking any active role in global financial markets. Increasing interdependencies among financial markets within economies and globally requires involvement of all nations, especially oil producing countries. Recent escalation in oil prices, although short-lived, increased these countries' shares in global liquidity causing trade imbalances and balance of payments disequilibrium in many oil-importing economies. ${ }^{1}$

\section{The United States Banking System}

The global financial crisis is a result of mismanagement and unethical practices by big financial institutions, speculators and policy makers in the United States. Due 
to the low level of regulatory measures and supervision by monetary authorities, banks in the United States were lending money on easy terms with inadequate credit checks on borrowers and with inflated appraisals of the quality of collateral on secured loans.

By doing so, easy credit has encouraged excessive consumption through borrowing, i.e., for years, the average American has been over-leveraged living on credit due to the generous offers and easy lending policies by banks. Such policies have created an artificial economy with an amount of money far exceeding the productivity of both the individual and the economy. Down payments on homes were close to nothing which encouraged those with no standing credit to acquire easy loans most of which were diverted to buying consumer goods and luxury products. It is rather difficult for any society to sustain such lavish consumption by having so many people living beyond their means. In contrast, moderation in consumption is the main principle for living in a Muslim society, i.e., in Islam living within one's mean is the right choice for development. In other words, excessive borrowing and overspending make the society more vulnerable to economic and financial downturn. In the view of David Testa, chief executive of Gatehouse Bank, which began operations in April as the fifth Islamic bank in Britain,

[i]nvestors traumatized by the credit crisis could seek comfort from the stricter rules imposed on lending by Islamic law, which bans some of the structures and financing methods that quickly unraveled during the US mortgage crisis. ${ }^{2}$

A bubble economy driven by irrational exuberance and greed led consumers to believe that prices of housing and stocks would always rise and the fear that markets may fail unthinkable. The economic system driven by capitalism seems to have run out of steam by its inability to sustain growth. In the view of the Philadelphia-based journalist Dave Lindorff,

[t]he truth is that we are not threatened by communism, by drug lords, or by Muslim Jihadists in any serious way. Rather, we have become our own worst enemy. The honest truth is that the US is technically bankrupt and in a state of chronic decline, and yet the nation persists in spending a trillion dollars a year on war and preparations for war, as though America were in mortal danger from foreign enemies. ${ }^{3}$

Islam is against such lavish spending if the economy is non-productive to support high consumption. Monopoly and excessive control over resources is not allowed in Islam to facilitate giving access to all individuals in society to share resources through work, management, knowledge and organisation. Earning profits is possible through work and trade resulting from real economic activities.

Owing to the size of the US financial system and its linkages to global financial markets, the financial crisis in the United States has generated a spill-over 
effect across the financial institutions and markets worldwide. Avoiding further deterioration in the global economy and minimising the risk of financial failure, especially in developing countries, requires greater cooperation among nations. The existing financial institutions, including the IMF and World Bank, are no longer in a position to manage international liquidity and maintain global financial stability. The global financial crisis will have destabilising effects on local economies both in industrialised and non-industrialised countries.

It is the unchecked greed of capitalism that generated the crisis. Hedge fund managers and rogue CEOs, practising irresponsible acts to maximise personal wealth, contributed to the crisis currently sweeping across the world. Among the most pernicious practices involved the dissemination of extremely risky derivatives. Use of derivatives like credit default swaps, also described as 'weapons of financial mass destruction', represent transactions involving an increase in capital measured in dollars but not in real assets. The main purpose behind credit default swaps is to increase bank income. A loan or bond may be issued by the bank to a second party covered by an insurance contract to protect sellers from expected losses. These credit default swaps do not represent real securities in the sense that "they're not transparent, aren't traded on any exchange, aren't subject to present securities laws, and aren't regulated". The motive behind such financial transactions is for big financial institutions to generate income. Investing in a credit default swap involves an insurance contract between two parties which provides protection against losses for both parties. According to one observer,

[c]redit default swaps are not standardized instruments. In fact, they technically aren't true securities in the classic sense of the word in that they're not transparent, aren't traded on any exchange, aren't subject to present securities laws, and aren't regulated. They are, however, at risk - all \$62 trillion of them. ${ }^{5}$

\section{The Islamic Financial System}

Islamic Finance is a component of the Islamic economic system driven by the principle of the sharī $a h$. Islamic finance exhibits humanistic features designed to promote social justice, endorsing equity and protecting individual right and freedom in the market place. Economic activities in Islam underscore the importance of individual right to ownership, making decisions, freedom of choice and cooperation. In an Islamic state, the shari 'a $h$ provides legal and ethical guidelines which strengthen market activities and minimise risks of failures. In this regard, the Islamic financial system aims at serving man through the creation of employment opportunities, increasing production of goods and services and sustaining development. Unlike capitalism, interest of the individual in Islam is served through the welfare of the 
Muslim community at large (ummah). For example, Adam Smith, the father of capitalism, postulates that the prosperity of a nation is a product of individual rational behaviour to make profit. More specifically, the work of the individual through the 'hidden hand' is responsible for the success of society. In Islam, such a proposition is rejected due to man's personal greed and lack of sufficient knowledge to make decisions. In other words, individual welfare is a derivative of society's welfare. Resources are not supposed to be allocated for the service of a few in society; rather, to be shared by all individuals. This implies that the interest of the individual will be served through the collective work of the whole community. However, recent research in economics has shown that "people cannot always pursue their long-term personal interest. From time to time, they must also rely on other people and take into account other people's interests as well as their own."

As a discipline, Islamic finance is relatively new compared to the existing financial systems including capitalism and socialism. The conventional financial system comprises secular and theoretical concepts the return on which is measured in interest payment. In contrast, Islamic finance exhibits religious features comprising prohibition of riba $\bar{a}$, ethical investment practice, economic incentive and social welfare. The Islamic financial system promotes Islamic ideals and promotes balance between man's religious needs and worldly requirements, i.e., return on Islamic investment is not necessarily measured in individual profits but by contribution to society. In addition, the concept of brotherhood in Islam is about cooperation and not competition. Gain from investment must be shared by all members of the ummah in accordance with the principles of equity instead of being concentrated in a few hands.

The social dimension of Islamic banking constitutes elements of fairness and equity to alleviate poverty and create wealth. In Islam, individuals are entrusted with the task of allocating resources efficiently to maximise returns and promote individual welfare. Human development - not output - is the main objective of the Islamic economy. Knowledge, information, health, food, shelter and the environment are the ultimate targets of the Islamic economic system. These are among the core fundamentals for promoting a just society. Islamic finance contributes to building such a society through the adaptation of various modes of financial and investment instruments capable of delivering with high efficiency and accountability. Thus, Islamic banking policies, in relation to lending and granting loans to customers, require careful review to ensure that investment is in compliance with the sharì'ah. The sharī'ah board, an independent body of religious scholars, usually supervises bank activities by providing final approval of decisions to be sure that they comply with the Islamic legal system. This practice instils legitimacy into investment activities to meet the socio-economic needs and contribute to the development of the society. 
Interest-free banking maintains no interest payments on non-productive investment implying that money creation must be linked to production of physical assets. Various modes of investment practised by Islamic banks involve business participation and partnership among investors in which both profit and losses are agreeable to all parties. In non-interest-free banking, bank transactions mainly take the form of interest income paid either to depositors or charges on lending to individuals and institutions. Owing to the creation of physical production and employment through bank lending using the Islamic mode of financing, the risk is usually minimised. However, unlike conventional banks, there is no guarantee that capital owners get their capital back or the share of the profit on their investment. It is rather a fair practice that in business both profit and loss should be taken into consideration. In addition, Islamic finance provides incentives for capital providers to earn higher returns on their investments compared to the interest payments by conventional banks. In addition, the potential success of Islamic enterprises is likely higher owing to the involvement of partners, especially in the case of mushärakah (joint venture). Islamic financial products, although having recently sputtered, grew rapidly in recent years, owing to their acceptance, particularly by non-Muslims, as an alternative to conventional finance. Assets of Islamic banks have exceeded US\$1 trillion reflecting the competitive advantage of Islamic financial products. Diversification of Islamic products includes issuing of Islamic bonds (șukuk $)$, project finance, equity financing and wealth management have helped Islamic banks to broaden their investment base and gain competitiveness. There is no doubt that financial globalisation has given greater circulations of Islamic financial products worldwide and has been able to attract foreign investors from non-Muslim countries. In a recent issue of the International Herald Tribune it was pointed out that,

[w]hile conventional banks worldwide are nursing losses of more than US\$ 400 billion from the credit crisis, Islamic banks are virtually unscathed. And they are playing up the contrast to scalded shareholders, bondholders and borrowers and fearful depositors. ${ }^{7}$

Rapid growth in financial globalisation, in recent years, has provided the Islamic banking industry with greater incentive to expand and take advantage of globalisation. There are several Islamic financial products sold worldwide by Islamic banks in non-Muslim countries or by Islamic windows through foreign banks. What is still lacking in banking operations by Islamic banks is the adaptation of a unified approach to standardise financial services. Also, Islamic banks must become creative and innovative to develop new financial products to gain comparative advantage over international banks. Building confidence and establishing rules including international regulatory standards prescribed by the Basel I and Basel II Accords allow Islamic banks to get acceptance worldwide. Such standards 
also provide investors with assurance about the viability of Islamic banks as an alternative to conventional banks.

\section{The Human Dimension of Islamic Banks}

The Islamic banking system carries duties and responsibilities similar to conventional banks, but they are constrained by the sharī'ah principles. Among other things, Islamic banks are not to charge interest on their transactions. The objective of Islamic banks is to serve the community by providing the necessary funding for stimulating economic growth and enhancing the social welfare. As financial intermediaries, these banks contribute to the economy by channelling savings into productive investment. Unlike conventional banks, Islamic banks impose strict guidelines on granting loans to ensure compliance with the shari ${ }^{-} a h$. The risk of doing business, though it exists, is expected to be less in Islamic financial markets owing to non-interest payment. Liabilities of Islamic banks are allocated for productive investment to meet the society's economic challenges. In addition, management of funds is subject to restrictions imposed by the socio-economic interest of the Islamic economy. Earnings of Islamic banks depend on profit generated from investment, and, therefore, regulatory measures on lending policies become an integral part of investment decisions. Mohsin Khan and Abbas Mirakhor explain:

Due to the fact that the return to liabilities will be a direct function of the return to asset portfolios and also because assets are created in response to investment opportunities in the real sector, the return to financing is removed from the cost side and relegated to the profit side, thus allowing the rate of return to financing to be determined by productivity in the real sector. Thus, in the Islamic system there is a much tighter link between the rates of return in the real and financial sectors than in the capitalist system. ${ }^{8}$

This implies that the financial sector in the Islamic economy is related to the productivity of the economy which constitutes less volatile trends compared to financial markets in capitalism. Speculative investment is usually linked to future trends driven by the expected rate of return, mainly interest rates. This makes the financial system highly sensitive to changes in interest rates. In the Islamic economy, the linkage between financial markets and real sectors reduces economic and financial fluctuations owing to the fact that the rate of return on investment is linked to the performance of investment. For example, under the mudarabah (profit sharing) system, the bank accepts deposits and uses them in partnership with investors. A contract is required for defining the terms and conditions between the two parties including the sharing of the profit. Depositors are paid a percentage of the total profit earned by the bank usually in the form of dividends. In this regard, money is paid to depositors only if profit is realised, which is in contrast to conventional 
banks where interest is paid in spite of profit or losses incurred by the bank. Thus, speculations about future trends in interest could have direct effect on the real sector affecting employment, inflation, income and growth, i.e. the economy is sensitive to changes in financial markets. Under such circumstances, the Islamic financial system promotes financial and economic stability due to the prohibition of interest.

At present, there are more than 300 Islamic banks in many countries worldwide. Total assets of these banks vary in size depending on each country's financial endowments and government backing of Islamic financial institutions. The growth in demand for financial products is expected to increase in the coming decades owing to the increase in Muslim population and rapid expansion of Islamic banks outside the Muslim world. Today, Muslims are more interested in their heritage and culture driven by the Islamic principles. Experience with development during the last several decades has not been satisfactory to induce growth and improve human development. Models, theories, ideas and systems imported from other civilisations could only provide knowledge and information but cannot be a substitute of indigenous knowledge. It is not possible to isolate socio-economic development in Muslim societies from traditional values and religious teachings.

The Islamic worldview contains a set of elements exhibiting ethical, moral, social, political, financial and economic values which are different from those practised in other societies. Core Islamic principles, notably prohibition of riba $\bar{a}$, cannot be modified to meet the challenges of the modern age. These challenges, however, are products of human errors and judgment based on worldly views and not attributed to religious teaching. Secularisation of Muslim societies has led to the penetration of non-Muslim theoretical, scientific, cultural, social, educational, economic and financial elements which are associated with growth and performance of Muslim societies. Life in Islam is more than just production of goods and services to satisfy man's material needs; it is also about enhancing his ethical values and obtaining spiritual fulfilment. It is within this framework that Islamic banking and finance must be practised in order to contribute to the development of Muslim societies. ${ }^{9}$

The Islamic financial system underscores the importance of financial discipline to avoid losses and promote market stability. An Islamic bank acts as an agent on behalf of depositors to invest their money and secure earning profits. In contrast, management of conventional banks represents owners who are interested in maximising profits. Discipline in the Islamic economy is guided by ethical considerations driven by the teaching of the sharī ah. Investment through Islamic banks requires creation of economic activities using the society's real resources. In this respect, the ultimate objective of Islamic banks is to enable society to become more productive. In the Islamic economy, capital is a product of production itself and should not be treated as a separate factor of production earning interest. It is the effort of the entrepreneur that uses capital goods to create value by managing, 
organising and supervising the enterprise. Islamic finance operates on the basis of profit/loss $(\mathrm{P} / \mathrm{L})$ reflecting the fact that in real life both profit and risk must be accounted for. Excluding risk from investment activities means providing protection for capital-owners at the expense of the rest of the society.

By operating on the basis of profit loss sharing (PLS) principle, the Islamic banking system exhibits greater financial and economic stability. Market risk is largely explained in relation to interest variation absent from the Islamic economy. Western economies are sensitive to financial variables, mainly interest rates, which usually spill over into the rest of the economy impacting income, prices, government revenues and expenditures, and employment. Earnings income in the Islamic economy must be created through work using factors inputs including labour and land. Money is useful if it is converted into physical capital through business activities. Capital providers earn a fixed share in the profit of the enterprise if the project is successful in earning profits. ${ }^{10}$

\section{Sharī'ah Compliance and the Prohibition of Ribā}

Being driven by religious codes and ethical principles, the Islamic financial institutions act as an economic agent on behalf the community. Depositors in Islamic banks are shareholders entitled to dividends obtained from profits and not income earned from interest. In other words, ownership of Islamic banks belongs to a large number of people and not to individuals or private enterprises. In an Islamic state, this implies that Islamic banks are owned by the community which makes decisions that serve the entire community instead of a few owners. Decisions and policies by Islamic banks support investment for promoting human development and meeting people's basic needs, involving investment not only in physical production, but also in knowledge creation, information dissemination, health care, water and environmental management. This implies that the Islamic financial institutions represent an integral element of the whole society and, therefore, their interest will be linked to the development of the society. In addition, Islamic banks collect the $z a k a \bar{h}$ - the obligatory Muslim 'alms tax', one of the 'five pillars' of Islam - and give to charities for helping members with disabilities, the poor and the needy. The prohibition of interest in Islam is due to social and economic considerations to promote justice and prevent discrimination. ${ }^{11}$

Islam provides comprehensive guidelines regulating how life is organised. Islamic banks bear great responsibility for promoting development in a Muslim society. Islamic banks are financial agents working on behalf of the public as partners sharing profits and incurring losses. In this respect, as shareholders, depositors of Islamic banks in principle authorise the bank to invest their money on their behalf in compliance with the $\operatorname{sharī'}^{\prime} a h$. When an individual saves, his saving gives rise 
to creation of an asset or a debt. But, as a rule, he has no power to decide which it will be. Conventional banks are lenders providing loans for investors in return for interest. Unfair and unjustified trading is rejected by Islam owing to the prohibition of harmful and non-productive activities in the Islamic economy. Risk is part of life and not taking risk violates sharī'ah principles. However, investors must be aware of risk and act to minimise the risk. For investors, risk is an opportunity to make profit and also a problem related to potential losses. In the Islamic economy, the financial system operates on the basis of profit-and-loss sharing (PLS) by sharing both profit and risk among partners. In contrast, conventional finance does not subscribe to such investment principles by eliminating risk from depositors. In other words, capital owners are exempted from risk taking by earning guaranteed income in interest payment. This gives rise to redistribution of resources in favour of capital owners at the expense of investors.

In an Islamic economy, the task of the banking system is to ensure wealth creation to sustain living. Consumption largely depends on income earned from work and not borrowed money. The celebrated medieval Muslim scholar Abū Hāamid al-Ghazālī (d. 1111) was of the view that knowledge and action are the two important features of an individual in society. ${ }^{12}$ In modern economies, mismanagement or misuse of money can have devastating impacts on human development causing poverty, social problems and political intolerance. Meeting the basic needs becomes essential for social equilibrium. Banks are supposed to contribute to socio-economic stability by allocating investment resources for meeting the society's basic needs. Bad governance and unethical practices by corporations have been among the main characteristics which governed the corporate world under capitalism. Without ethical guidelines, the society can no longer afford to promote justice and equity.

Islam makes it clear that $r i b \bar{a}$ is prohibited, and, therefore, all financial transactions in the Islamic economy must refrain from dealing with rib $\bar{a}$. It refers to the access amount above the principals charged by individuals or financial institutions. Although the prohibition of rib $\bar{a}$ has been interpreted differently by Islamic scholars and various schools of Islamic jurisprudence (fiqh), the most important argument, perhaps, is its violation of the principles of social justice. All forms of injustices, exploitations and inequalities violate the shari 'ah teachings and, therefore, Islam condemns those who practise ribā. Historically, the prohibition of interest goes to the era before Islam where the Old Testament considered usury as a sin that must be avoided. However, in modern economics, interest represents a cost of borrowing money. Interest impacts the level of economic activities by influencing investment, income and employment. Higher interest rates will have an adverse impact on investment expenditure by discouraging people from investment in productive activities. Central banks usually interfere to manipulate the economy by reducing interest rates and provide incentives for investment in the economy. 
In addition, in countries where national debt accounts for a high percentage of GDP, serving the debt through interest payments has brought the economies of these countries close to collapse. In the last two decades, Argentina, Mexico, Russia, the least developed and some Asian countries suffered from shortages of liquidity for serving their debt. A yearly transfer of billions of dollars from poor to rich countries to service interest payments implies that the poor people are feeding the rich. This implies that a large share of output produced in developing countries is used to serve the debt instead of being used as investment to alleviate poverty and promote human development. Globally, high debt reduces a nation's capacity to import which, in turn, spurs global recessions by reducing demand for goods and services traded in global markets. Under such circumstances, conventional banks become exploitative by linking lending and investment to interest rates. This is, in contrast, to non-interest banking systems, which disallow interest payment on investments in order to preserve market competition and provide equal opportunity to all individuals. Market imperfections usually discriminate against the poor, non-owners of capital, unprivileged groups, minorities and women. Thus, following the shari ${ }^{-} a h$ guidelines could restore equity and justice by imposing ethical and moral restrictions on business activities to preserve human rights and increase falāh, which is the Islamic term for 'success' (especially from self-improvement), 'happiness' and 'well-being'. According to Ziauddin Ahmad,

[i]t has been pointed out that interest based on debt financing is a major factor in causing economic instability in capitalist economies. It is easy to see, for example, how the interest based system intensifies business recessions. As soon as banks find that business concerns are beginning to incur losses, they reduce assistance and call back loans, as a result of which some firms have to close down. This increases unemployment resulting in future reduction in demand, and the infection spreads. Islamic banks, on the other hand, are prepared to share in losses which reduce the severity of business recession and enable the productive enterprises to tide over the difficult periods without a shut down. Islamic banking has, therefore, to be regarded as a promoter of stability rather than a conduit of instability. ${ }^{13}$

\section{The Concept of Money and Investment in Islam}

Investment in the Islamic economy must meet society's objectives to satisfy people's basic needs. In Islam, production of luxury comes after the essentials are met to combat poverty and preserve man's divinity. Monopoly and concentration of wealth in the hands of a few are against the Islamic justice system. It is through work that man is supposed to earn income and accumulate wealth and not through earning income from investment in interest. Investment in Islam comprises both risk taking 
and earning profit. In other words, earning profits alone cannot be justified unless suppliers of capital agree to accept losses. The tendency to accept risk has redistribution effects by preventing wealth from being concentrated in a few wealthy individuals. In contrast, earning interest has opposite effects on income distribution where owners of capital enjoy earning income for no risk being taken. This is perhaps one of the justifications of prohibiting ribā in Islam. Productive investment requires creation of physical assets which add value to society's output.

Economic activities involve allocation of resources including labour to ensure job creation and induce rapid economic growth. The Islamic banking system facilitates such activities by providing loans that guarantee productive investment for maximising the society's material wealth. Unlike conventional banks, Islamic banks do not necessarily maximise profits; rather, social welfare is their ultimate objective. Thus having money change hands without creation of an asset is not acceptable from an Islamic point of view. The Islamic economic system advocates building a society aiming at achieving falāh or success in both this life and the hereafter. According to Hasanuzzaman, "[f]alāh as an all-embracing concept provides a motivation to behave properly". ${ }^{14}$

The role of money in the Islamic economy is to stimulate market demand in order to sustain employment and growth. The Qur'ān condemns those who hoard money because of the negative effects of hoarding on circulation and, hence, on production. In modern economies, circulation of money plays a stimulating role in economic activities providing incentives for investment and demand for production. Money usually enlarges the economy's capacity to produce goods and services leading to employment of resources including labour. In conventional finance, money is treated as a commodity bought and sold at a specified interest payment. Here, interest is a price for the use of money paid either to the depositors or borrowers. In other words, the return on investment is measured in the amount of interest paid which also represents the profit of an entrepreneur. Since interest is prohibited according to the shari 'ah, money can only be useful if reinvested in the creation of real assets. That is to say, money cannot create wealth without creating assets. The latest financial crisis in the west is a product of this kind of transaction where banks driven by earning money opted for investing in the paper rather than in the real economy. This, in turn, has inflated the market by creating huge financial debt that was not possible to serve. Easy lending policies and lack of transparency led banks to offer large sums of money to people with little or no collateral. Lax credit terms provided by lending institutions opened the door for borrowers to divert funds to consumer purposes instead of retaining home or equity investment in productive sectors of the real economy. ${ }^{15}$

An increase in the amount of money above the optimum needed for buying the output produced causes inflation instead of increasing output. In recent years, in Gulf 
countries, increases in oil prices led to increases in liquidity causing demand for goods and services to increase sharply. Along with speculation, rising demand led prices to go up impacting the value of money and the cost of living. In small economies, the productive capacity of the economy is limited and, therefore, increases in the quantity of money will affect prices more than stimulating production.

Islamic investment is equity financing based on pooling money obtained through depositors used mainly for the creation of real economic activities. Under such circumstances, banks must be extra careful in making loans to minimise risk and protect depositors' money. Lending by banks requires careful assessments to make sure that any investment contributes to the interest of both depositors and society. Default on payment of principal is likely to be reduced under equity financing owing to the fact that losses are shared by all partners. In Islam, income from trade is allowed owing to the labour contents in its production whereas income from interest is prohibited because it is not related to engagement of labour. In trade, market transactions usually include physical products traded among buyers and sellers, the reward of which is profit. Payment of interest does not involve usage of labour but only time which covers the period until the principal is paid back. Here the reward is not paid for any good or service being created in the economy. Furthermore, in trade there is a risk to be considered which comes in the form of potential loss of capital or other circumstances that are beyond the power of investors. According to one scholar,

[e]very economy, sooner or later, is likely to reach a point where it becomes unprofitable to extend or undertake new investment without reducing the rate of interest to a very low level approaching zero. This is most likely to be experienced in the modern rich and industrialized countries where the opportunities for investment gradually become scarce. And as marginal efficiency of capital comes down to the level of the rate of interest, future production of capital assets is not undertaken. Under these circumstances, it is absolutely necessary to lower the rate of interest (probably to zero) in order to stimulate investment, otherwise the country will be impoverished. ${ }^{16}$

In response to the global crisis, Islamic finance provides greater protection. As Umer Chapra argues, Islamic finance minimises the impact of crisis:

It introduces greater discipline into the financial system by requiring the financier to share in the risk. It links credit expansion to the growth of the real economy by allowing credit primarily for the purchase of real goods and services which the seller owns and processes, and the buyer wishes to take delivery. It also requires the creditor to bear the risk of default by prohibiting the sale of debt, thereby, ensuring that he evaluates the risk more carefully. ${ }^{17}$

ICR 1.2 Produced and distributed by Pluto Journals ICR.plutojournals.org 
In conventional banks suppliers of capital earn profits but without taking risk. In contrast, investors who are willing to take risk will be left at the mercy of the market earning little or no profit at all. Suppliers of capital usually get fixed return in interest payments. The entrepreneur usually does most of the work including providing managerial and organisational skills. Such investment practices create inequalities by favouring those with capital leading to concentration of wealth in the hands of a few. In developing countries, including Muslim nations, interest rates could discourage investment in high priority projects even though these projects might be of high value to socio-economic development of the society. In the case of borrowing, interest rates represent costs which investors must pay before making profit. Producers usually pass the increase in cost to consumers causing prices to go up:

The right approach, therefore, will be to study modern banking separating out the good things in the system and finding ways and means to benefit from it without involving interest. We can adopt such useful and good things like the organizational, managerial and structural side of banking while leaving the evils of the system, like the unsocial and harmful practices of interest, speculative dealings and profiteering to others. ${ }^{18}$

As an alternative to interest, investment in the Islamic economy constitutes several forms of investment including muḍ̄arabah, mushārakah, murābahah (sale of goods at a price, which includes a profit margin agreed to by both parties), bay 'al-salam (contract of deferred delivery), istisna' ' (a contract of exchange with deferred delivery, applied to specified made-to-order items), and ijārah (selling benefit or use or service for a fixed price or wage) among others. Islam is against interest payment encouraging in return investment in trade and business activities. In other words, loans granted by the banking system must be invested in the real sectors creating goods and services. Such will lessen the impact of speculations and cyclical fluctuations in financial markets on the rest of the economy. The current financial crisis is spilling over into the local economies both locally and globally. These modes of financing provide mechanisms for allocation of resources on the basis of profit and loss sharing principles. As an intermediary, the Islamic banking system provides depositors with several choices to invest their money. However, most investment according to the Islamic modes of finance requires both capital and labour to be shared by all parties involved in investment, and, therefore, risk will be shared by everybody in the partnership. Unlike conventional finance where the return on investment is known in advance, in Islamic finance, profit will only be known after completion of the project and realisation of profit. On the other hand, the risk in Islamic banks is expected to be less than in conventional banking owing to the partnership between capital providers, or depositors and investors. Investment in the Islamic economy is based on equity financing by pooling depositors' funds to finance 
projects. Most modes of financing in Islamic financial markets and institutions exhibit short-term financing, mainly murābaḥah, ijārah and muḍārabah financing, which makes risk in Islamic financial institutions more diversified instead of being subject to interest payments alone.

In the Islamic economy, the voluntary sector plays an important role in stimulating aggregate demand and enhancing growth potential. Unlike the conventional economy, Muslims voluntarily spend in the forms of zakāh, awqāf (inalienable religious endowment; plur. of waqf), charity, and spending in the way of Allāh to build mosques, hospitals and schools. Such expenditures help the economy to generate linkages and stimulate demand.

Money in the Islamic economy is a means to facilitate transactions. The role of money is to serve as a medium of exchange and unit of account but not as a store of value. The Qur'ān, for example, rejects hoarding to ensure that money remains in circulation serving the economy. In modern economics, interest is paid for those who are willing to sacrifice present consumption with future consumption by saving their money. The income paid to savers cannot be justified owing to the fact that the money was earned for no work being done and, in addition, it brings no added value to the economy's output. Without employment of resources, investment in the Islamic economy cannot be justified. ${ }^{19}$ Even depositing money in a bank may not justify that investment will be taking place because the individual saver has no say in what his/her money will be used for.

\section{Conclusion and Recommendations}

In this article, an overview of the relationship between Islamic finance and the global financial crisis has been introduced. The Islamic banking services system, despite its young history, has grown rapidly in recent years reflecting rising market demand both in Muslim and non-Muslim countries. Operations and activities of Islamic financial institutions follow religious guidelines imposed by the shari $a h$ teachings. Islam advocates individual freedom and promotes social justice to ensure social falāh. Violation of these principles amounts to immoral and unethical practices which usually create imbalances within society. The Islamic financial system is an integral element of the Islamic way of life which exhibits individual rights, social and economic justice, prohibition of riba and environmental degradation. The social orientation of Islamic investment highlights the importance of allocation of resources in favour of the public interest instead of individual monopolistic control over resources.

The global financial crisis has brought a lack of confidence in the global financial system under capitalism. Market freedom has strengthened the position of monopolies and individual control over financial institutions to enrich a few 
people and corporations at the expense of society. Owing to lack of supervision and weak government regulations, the banking system was able to manipulate the financial system and divert huge sums of money to serve special interest groups. In contrast, limited freedom under the $\operatorname{shar}^{\prime}$ 'ah principles has imposed ethical and moral constraints on financial activities in the Islamic financial system. It is the service of the community that must come first under the Islamic financial system by facilitating growth through the creation of real output. Investors share not only profits but they also share the risk. In the Islamic economy, investment adds economic value measured in terms of increase in output and employment opportunities. Keeping money in the bank generates income without work providing capital owners secured profits. Islam rejects the payment of a predetermined fixed amount on bank deposits because of its violation of the principles of justice. Thus, providing credit according to the Islamic sharī'ah must be linked to sustaining socio-economic development and enhancing human well-beings. Sharing profits and losses benefits both borrowers and lenders through risk reduction and equity in income distribution. In Islamic finance, lenders and borrowers are partners working for their own interest.

There are still several challenges facing Islamic banking and finance that need to be overcome in order to increase global competitiveness. The time perhaps is suitable for these institutions to strengthen their global position by providing alternative financial services driven by innovation and development of new products. The global financial crisis is a product of institutions driven by serving the interest of owners of capital with little or no attention paid to human development. Investment according to Islamic finance is human centred the benefit of which will be to the entire society. In addition, being in compliance with the sharī $a h$, investment has to be guided by ethical principles.

\section{Notes}

1. For details about the impact of higher oil prices on global liquidity see Amer Al-Roubaie, "The Impact of Higher Oil Prices on Global Liquidity", Al-Shajarah: The Journal of the International Institute of Islamic Thought and Civilization [ISTAC, Kuala Lumpur] 13, no. 12 (2008), 142-78.

2. International Herald Tribune, 18 August 2008.

3. See Dave Lindorff, "The Ugly Truth: The American Economy is Not Coming Back", Counterpunch (30 January-1 February 2009), available online at http://www.counterpunch.org/ lindorff01302009.html (accessed on 4 August 2009).

4. See "The Real Reason for the Global Financial Crisis: The Story No One's Talking About", The Market Oracle, 18 September 2008, available online at http://www.marketoracle.co.uk/ Article6335.html (accessed on 4 August 2009).

5. Ibid.

6. Roger Leroy Miller, Economics Today (Boston: Addison-Wesley, 2009, 15th ed.), 9-10.

7. International Herald Tribune, 18 August 2008. 
8. Mohsin Khan and Abbas Mirakhor, "Monetary Management in an Islamic Economy", Journal of King Abdulaziz University: Islamic Economics 6 (1994), 10.

9. See Syed Muhammad Naquib Al-Attas, Prolegomena to the Metaphysics of Islam (Kuala Lumpur: International Institute of Islamic Thought and Civilization [ISTAC], 1995) and Alparslan Açikgenç, Islamic Science: Towards a Definition (Kuala Lumpur: ISTAC, 1996).

10. For detailed treatments on Islamic banking see: Muhammad Ayub, Understanding Islamic Finance (London: John Wiley and Sons Ltd, 2007); Muhammad Nejatullah Siddiqi, "Islamic Banks: Concept, Precept and Prospects", Review of Islamic Economics 9 (2000), 21-35; Abdus Samad, Norman Gardner, and Bradley Cook, "Islamic Banking and Finance in Theory and Practice: The Experience of Malaysia and Bahrain", American Journal of Islamic Social Sciences 22, no. 2 (2005), 69-86.

11. See Umer Chapra, "Why Has Islam Prohibited Interest?" Review of Islamic Economics 9 (2000), 5-20; and Muhammad Samiullah, "Prohibition of Riba (Interest) and Insurance in the Light of Islam”, Islamic Studies 21, no. 2 (Summer 1982), 53-76.

12. See Amer Al-Roubaie, "Islamic Economics: A Reflection on Al-Ghazālī’s Contribution", unpublished paper presented at the International Conference on Al-Ghazālī’s Legacy: Its Contemporary Relevance, held at the International Institute of Islamic Thought and Civilization (ISTAC) in Kuala Lumpur, 24-27 October 2001.

13. Ziauddin Ahmad, "Islamic Banking: State of the Art", Islamic Economic Studies 2, no. 1 (June 1994), 1-34.

14. See S.M. Hasanuzzaman, "Defining Islamic Economics", Finance in Islam (2005), available online at http://www.financeinislam.com/article/1_36/1/191 (accessed on 4 August 2009).

15. See Mahmud Abu Saud, "Money, Interest and Qirad", IIUM Journal of Economics and Management 10, no. 1 (2002), 1-30.

16. Afzal-ur-Rahman, Economic Doctrines of Islam, 4 vols (Lahore: Islamic Publications, 1990), 3:119.

17. Umer Chapra, "The Global Financial Crisis: Can Islamic Finance Help?" New Horizon, no. 170 (January-March 2009), available online at http://www.newhorizon-islamicbanking.com/index.cf $\mathrm{m}$ ? section $=$ academicarticles\&action $=$ view $\&$ id $=10733$ (accessed on 4 August 2009).

18. Afzal-ur-Rahman, Economic Doctrines of Islam, 4:271.

19. Sheikh Mahmoud Ahmed, "Interest and Unemployment”, Islamic Studies 8, no. 1 (March 1969), 9-30. 